\title{
Who Owns these Records? Authority, Ownership, and Custody of Iraq's Baath Party Records
}

Archives acquire records through a variety of circumstances. While they often have a direct and ongoing relationship with record creators (such as government records and national repositories), archives may also accept donations from record creators that align with the mandate of their organization. Less commonly, archives also face the possibility of acquiring records or objects from an entity that did not create them, which raises questions about title and the authority to act. Research notes, for instance, may be owned by the funder if conducted as work-for-hire, or the intellectual property rights might be held by a university. There may be issues of consent from human subjects of research, particularly Indigenous communities, that affect whether and how records may be donated and used. Although donors may be acting in good faith, they create dilemmas for archivists about whether they can accept those records and, if they do accept the records, what limitations are imposed by the nature of the donation. Such dilemmas are also informed by the challenges of what archivists can or should do with records they already possess that have unclear or unknown ownership. The case of Iraq's Baath Party records has an international character and exceptional circumstances that likely places it outside the experience of most archives, but the core questions of who owns the records and who has the authority to take actions in regard to those records is relevant in a wide range of circumstances. It is particularly informative when considering whether and how the principle of inalienability can complicate determinations of ownership.

Following the US-led invasion of Iraq in 2003, Baath Party records were collected, exported, and transferred by the Iraq Memory Foundation (IMF) to the Hoover Institution (HI) at Stanford University. Although the IMF was well-intentioned and acted during a period of crisis within an evolving, but generally unstable, situation to secure an important cultural record, its actions were also problematic due to questions of ownership and the authority to act. Ownership is an integral issue in archives as it defines who has the authority to reproduce, provide access to, dispose of, or transfer records and can be particularly difficult to determine when records and objects straddle the line between private and public ownership such as the papers of public officials. Although these records traveled to the US through

๑) 2019 by Sarah Wilkinson (CC BY-NC [https://creativecommons.org/licenses/by-nc/4.0/]). 
extraordinary circumstances, this is far from the only case in which inalienability might play a role (for example, the records of sovereign Indigenous nations). In such cases, archival ethics and best practices can play an important role in untangling the complicated mixture of legal, moral, and ethical issues at hand. However, this article will not consider whether the collection and seizure of these records constituted a war crime, as this has been considered elsewhere. ${ }^{1}$ Such questions are not the only consideration in evaluating the appropriateness of their transfer to the US and the HI.

The stories and arguments behind the Iraqi records' custody are full of open questions. Does the current government of Iraq own these records? What are the implications for the actions of the Iraq Memory Foundation and the Hoover Institution? Both the legal nature of cultural ownership and memory are important considerations for collecting institutions at any level, particularly given the legal entanglements such as privacy and copyright concerns that accompany these records. In this article, I argue archival principles accepted by the West provide a basis for concluding that these records should be considered the property of the Iraqi government and should have neither been transported to the US nor transferred to the Hoover Institution without its authorization, and that authorization must be grounded in Iraqi legislation. This article thus provides a case study in the legal considerations for determining the appropriateness of acquiring a collection with unclear ownership, particularly those for which the principle of inalienability might apply. Situating the discussion within the historical context of the return of records seized during World War II, which was essential in establishing the principle of inalienability for archival records, this article will turn to the case itself, followed by an in-depth analysis of the question of ownership and the authority to collect, export, and transfer these records.

\section{Historical Context}

Cultural property is defined as "objects that have artistic, ethnographic, archaeological, or historic value." ${ }^{2}$ Given the number of UNESCO treaties and their accompanying national legislation, the idea that cultural property merits protection appears to be a relatively unobjectionable idea. In reality, international norms for the treatment of cultural property in armed conflict slowly evolved from an assumption that "to the victor go the spoils" to the 1954 UNESCO Convention for the Protection of

1. For a discussion of this question, see Michelle Caswell, “"Thank You Very Much, Now Give Them Back': Cultural Property and the Fight over Baath Party Records," The American Archivist 74, no. 1 (2011): 211-40; Douglas Cox, "Archives and Records in Armed Conflict: International Law and the Current Debate over Iraqi Records and Archives," Catholic University Law Review 59 (2010): 1001-56; Bruce P. Montgomery, "Immortality in the Secret Police Files: The Iraq Memory Foundation and the Baath Party Archive," International Journal of Cultural Property 18, no. 3 (2011): 309-36.

2. John Henry Merryman, “Thinking About the Elgin Marbles," Michigan Law Review 83, no. 8 (1985): 1888 . 
Cultural Property in the Event of Armed Conflict. ${ }^{3}$ World War II was a significant turning point in this evolution due to the unprecedented scale of looting and destruction of cultural property. Although numerous sources detail the Nazi mania for art and culture, ${ }^{4}$ the looting of archival material has received significantly less attention. Despite the inattention, "never before had archives been subjected to such calculated destruction, or to looting on such a scale as was wrought by the Nazis across the Continent. And then, at the end of the war, as if in retribution, Soviet authorities engaged in archival plunder that rivaled that of their vanquished foe."'5

The return of that material, however, has been an uneven process. While almost all archival material looted by the Nazis from Soviet territory both survived and has long since been returned to Russia (with some known exceptions), ${ }^{6}$ the return of German archival materials from Russia has been less successful. Before examining this case, it should be noted that the US is not blameless either as it often exploits and makes copies of records before it returns them. ${ }^{7}$ Moreover, Nazi Party and SS records are available on microfilm from the National Archives and Records Administration as are records relating to Japanese war crimes. ${ }^{8}$ Furthermore, many records relating to Germany and Japan were not declassified and released until 2007. ${ }^{9}$

From the 1950s to the 1980s, Soviet-held materials were returned to Eastern Bloc countries. Russia acknowledged the existence of additional materials after the fall of the Soviet Union, at which point restitution began to be discussed. ${ }^{10}$ Agreements were made with countries such as the Netherlands (1992), Belgium (1993), France

3. For a comprehensive examination of the history of cultural property in armed conflict and the evolution of its protection, see Wayne Sandholtz, Prohibiting Plunder: How Norms Change (New York: Oxford University Press, 2007).

4. See, for instance, Hector Feliciano, The Lost Museum: The Nazi Conspiracy to Steal the World's Greatest Works of Art (New York: Basic Books, 1998); Jonathan Petropoulos, The Faustian Bargain: The Art World in Nazi Germany (Oxford: Oxford University Press, 2000); Lynn H. Nicholas, The Rape of Europa: The Fate of Europe's Treasures in the Third Reich and the Second World War (New York: Vintage Books, 1995).

5. Patricia Kennedy Grimsted, "Displaced Archives and Restitution Problems on the Eastern Front in the Aftermath of the Second World War," Contemporary European History 6, no. 1 (Mar. 1997): 30, https: / / doi.org/10.1017/S0960777300004045.

6. Grimsted, "Displaced Archives and Restitution Problems on the Eastern Front in the Aftermath of the Second World War," 39-44.

7. Bruce Montgomery, "Saddam Hussein's Records of Atrocity: Seizure, Removal, and Restitution," American Archivist 75, no. 2 (Oct. 2012): 334-36, https:/ / doi.org/10.17723/aarc.75.2.047h561410267138; Gerhard L. Weinberg, "German Documents in the United States," Central European History 41, no. 4 (2008): 555-67, https:// doi.org/10.1017/S0008938908000848.

8. NARA, "Nazi Party and SS Records on Microfilm," National Archives, available online at https:// www.archives.gov/research/captured-german-records/nazi-party.html [accessed 17 March 2019]; Greg Bradsher, "Japanese War Crimes and Related Topics: A Guide to Records at the National Archives" (National Archives and Records Administration, n.d.).

9. Nazi War Crimes \& Japanese Imperial Government Records Interagency Working Group, "Final Report to the United States Congress" (Washington, DC: National Archives and Records Administration, 2007).

10. Grimsted, "Displaced Archives and Restitution Problems on the Eastern Front in the Aftermath of the Second World War," 59-60. 
(1992), and Germany (1992) ${ }^{11}$ Unfortunately, however, the Russian Duma halted the returns, citing the lack of supporting international and domestic laws. ${ }^{12} \mathrm{By}$ 1998, Russia put in place a new law, "On Cultural Valuables Displaced to the USSR as a Result of the Second World War and Located on the Territory of the Russian Federation," which effectively nationalized some cultural property taken by Russia during World War II as

the official Russian patriotic position today follows Stalin's decree that "to the victor go the spoils." Those transfers to the Soviet Union were carried out legally after the war as legitimate compensation, as opposed to Nazi illegal seizure and destruction of cultural property during the war. These spoils of war have today become symbols of victory, which nationalist politicians seek to preserve at all cost. ${ }^{13}$

Constitutional challenges to the law produced a legal distinction between "aggressor countries," which are not entitled to the return of their cultural property, and countries that either were victims of Nazi Germany or fought against it, which were entitled to the return of the cultural property. ${ }^{14}$ This distinction, however, is not supported by international law or archival practice.

In some cases, however, the legislation provided a basis for resuming the return of archival materials. Under the new law, repatriation claims have to be negotiated on a state-to-state basis and must be pursued via the Federal Archival Agency (Rosarkhiv) in addition to the actual repository. ${ }^{15}$ This is somewhat unusual for cultural property claims, as relatively few cases involve diplomatic negotiations. Archives have since been returned to Liechtenstein (1996), Great Britain (1998), France (1994, 2000), Belgium (2002), the Netherlands (2001, 2003), Luxembourg (2003), and Austria (2009), as well as one set of private papers (Rothschild, 2003). ${ }^{16}$ Unfortunately, however, despite the two bilateral agreements between Russia and Germany (1990 and 1993), as well as a 1992 signed agreement between Rosarkhiv

11. Patricia Kennedy Grimsted, "Why Do Captured Archives Go Home? Restitution Achievements under the Russian Law," International Journal of Cultural Property (2010), 293-297, https: / doi. org/10.1017/S0940739110000123; Grimsted, "Displaced Archives and Restitution Problems on the Eastern Front in the Aftermath of the Second World War," 62-64.

12. Patricia Kennedy Grimsted, "Legalizing 'Compensation' and the Spoils of War: The Russian Law on Displaced Cultural Valuables and the Manipulation of Historical Memory," International Journal of Cultural Property 17 (2010): 221-22.

13. Patricia Kennedy Grimsted, “'Trophy' Archives and Non-Restitution: Russia’s Cultural 'Cold War' with the European Community,” Problems of Post-Communism 45, no. 3 (1998): 4, https:// doi.org/10.1080 /10758216.1998.11655785.

14. Grimsted, "Legalizing 'Compensation' and the Spoils of War,” 232-33.

15. Grimsted, "Legalizing 'Compensation' and the Spoils of War," 234.

16. Grimsted, "Why Do Captured Archives Go Home?" 292; Patricia Kennedy Grimsted, "Progress in the Return of Displaced Archives from Russia: Steps Forward and Hurdles Ahead," Art Antiquity and Law XV, no. 3 (2010): 226-31. 
and the Budesarchiv, no German records have left Russia since 1990 as their return is now prohibited under Russian law. ${ }^{17}$ Russia's attitude toward the return of archives was far enough outside international norms and expectations that, as part of a statement of intent to join the Council of Europe in 1996, it agreed "to settle rapidly all issues related to the return of property claimed by Council of Europe member states, in particular the archives transferred to Moscow in 1945." ${ }^{18}$ Its actions, or inactions, were seen as violating the principle of inalienability, which "prevents [public records] from being given, surrendered, or transferred to anybody except those the law allows to possess them." ${ }^{19}$ Public archives, after all, are closely associated with territory and the idea that "records follow the flag." ${ }^{20}$

During the second half of the twentieth century, the principle of inalienability was articulated in increasingly strong terms. ${ }^{21}$ Archives were explicitly included in the 1954 UNESCO Convention for the Protection of Cultural Property in the Event of Armed Conflict, an inclusion that was endorsed by a 1976 UNESCO report denying a special right to acquire archives through occupation. ${ }^{22}$ Archivists also began to reaffirm the principle of inalienability, often specifically in relation to displaced World War II archives. For instance, the 1961 International Conference of the Round Table on Archives issued a resolution stating that "it is desirable to call on archival institutions and archivists all around the world, asking them to take suitable measures for returning to their rightful owners archives groups and documents which have been displaced during World War II." ${ }^{23}$ Again, in 1977,

the Round Table reaffirm[ed] the right of each state to the recovery of archives which are part of its archival heritage and which are now kept outside its territory, as well as the right of each national community to have access, under agreed conditions, to records belonging to other countries and relevant to its own history and to copy them. ${ }^{24}$

In 1994, the International Conference of the Round Table on Archives reiterated that "the accepted archival principles that archives are inalienable and imprescriptible, and should not be regarded as "trophies" or as objects of exchange." 25 Finally, in 1995,

17. Grimsted, "Progress in the Return of Displaced Archives from Russia," 238.

18. Grimsted, "Legalizing 'Compensation' and the Spoils of War," 227-28.

19. Richard Pearce-Moses, A Glossary of Archival and Records Terminology and Information Sciences (Chicago: Society of American Archivists, 2005), 200.

20. Ernst Posner, "Effects of Changes of Sovereignty on Archives," American Archivist 5, no. 3 (1942): 142.

21. For a detailed overview of this process, see Patricia Kennedy Grimsted, Trophies of War and Empire: The Archival Heritage of Ukraine, World War II, and the Politics of International Restitution (Cambridge, MA: Harvard University Press, 2001), 83-86.

22. Grimsted, "Progress in the Return of Displaced Archives from Russia," 298.

23. Hervé Bastien, ed., "Reference Dossier on Archival Claims," (International Council on Archives, 1995), 43.

24. Bastien, "Reference Dossier on Archival Claims," 43.

25. Bastien, "Reference Dossier on Archival Claims," 46. 
the International Conference on Archives published a position paper stating that "national laws agree in conferring the status of inalienable and imprescriptible public property on public records. The alienation of public archives can therefore only occur through a legislative act of the State which created item. ${ }^{.26}$ Even Russia acknowledged this principle in its 1992 agreement with France: "in accordance with international practice, the Sides recognize the inalienable nature of public archives and shall return such of these as, being in the possession of one of the Sides, ought to belong to the other." ${ }^{27}$ Thus, in addition to the actual return of archival materials achieved following the fall of the Soviet Union, the issue of their repatriation has helped define expectations for the treatment of displaced public records.

In practice, however, adhering to the principle of inalienability can be difficult. The question of successor states complicates repatriations, particularly when multiple states are created. ${ }^{28}$ There are cases in which records had to be "repatriated" to a country in which they were never located, such as for the South African liberation movements, which had to create records outside South Africa from the 1960s to 1990s. ${ }^{29}$ There can also be challenges from diasporic records and questions that arise from forced migration. ${ }^{30}$ In other instances, it has been argued that inalienability is an inappropriate principle as nongovernmental actors are the more trustworthy repositories for records documenting human rights abuses. ${ }^{31}$ Indeed, not every government wants the return of records. For example, although the US was willing to transfer custody of Panamanian records seized in 1989, Panama was reluctant to accept the records due to the sensitivity of the documents. ${ }^{32}$ Even countries such as the US, which has a history of returning foreign records, has some notable failures in terms of the principle of inalienability such as its decision to treat capture German World War II records as "American," which made their return to Germany in 1953 a "donation." 33

26. International Council on Archives, "The View of the Archival Community on Settling Disputed Archival Claims" (Guanzhou, China, April 10, 1995).

27. Grimsted, "Why Do Captured Archives Go Home?” 297.

28. Angeline S. Kamba and Peter C. Mazikana, "Archive Repatriation in Southern Africa," Information Development 4, no. 2 (1988): 79-85, https://doi.org/10.1177/026666698800400202; Posner, "Effects of Changes of Sovereignty on Archives."

29. Mpho Ngoepe and Sidney Netshakhuma, "Archives in the Trenches: Repatriation of African National Congress Liberation Archives in Diaspora to South Africa," Archival Science 18, no. 1 (March 2018): 52, https:// doi.org/10.1007/s10502-018-9284-9.

30. W. Gerald Heverly, "Virtual Repatriation: The Pittsburgh-Konstanz Archival Partnership," RBM: A Journal of Rare Books, Manuscripts, and Cultural Heritage 6, no. 1 (Mar. 1, 2005): 34-43, https: / / doi. org/10.5860/rbm.6.1.240; James P. Niessen, "Heritage and Repatriation in the History of Habsburg and Hungarian Archives,” Hungarian Cultural Studies 11 (Aug. 6, 2018): 136-43, https:/ / doi.org/10.5195/ AHEA.2018.327.

31. Michelle Caswell, "Rethinking Inalienability: Trusting Nongovernmental Archives in Transitional Societies," American Archivist 76, no. 1 (2013): 113-34.

32. Douglas Cox, "The Lost Archives of Noriega: Emancipating Panamanian Human Rights Documents in U.S. Military Custody," Boston University International Law Journal 32 (2014): 56.

33. Cox, "Archives and Records in Armed Conflict," 1023. 
Adding to these complications, there are conflicting ideas of inalienability. In 2011, France returned nearly 300 volumes of Korean royal archives that had been seized during an 1866 military campaign through a renewable five-year loan because a French administrative tribunal had declared the materials as inalienable French property. ${ }^{34}$ Despite these challenges, however, inalienability remains one of the key principles in determining the proper home for public records. The question then arises: if inalienability is an important principle for determining the proper disposition of archival records, how did the Iraq Baath Party records end up in the U.S. and why are they still there?

\section{Iraqi Archives}

In 2003, the records of Iraq's former ruling party, the Baath Party, were collected by Kanan Makiya, founder of the Iraq Memory Foundation (IMF), an American-based private organization. A prominent Iraqi exile with ties to the Bush administration, Makiya located the records and transported them to his parents' home inside Baghdad's Green Zone. For this, Makiya claims to have had permission from the Coalition Provisional Authority (CPA). Although the IMF originally intended to found a private institution in Iraq to house and make available these records, it was decided that Iraq had become too dangerous. Instead, it made an agreement with the US military to export the documents to the US, where the digitization of the records was completed. In exchange, the IMF agreed that the military could retain a copy of the digitized records. In 2008, the IMF entered into a five-year agreement with Stanford University's Hoover Institution (HI) to house, preserve, and restore the records. This decision was opposed by Saad Eskander, Director of the Iraqi National Library and Archive (INLA), who sought their repatriation to Iraq. According to Eskander, these records are the inalienable public property of Iraq and thus belong in its national archive. Although Makiya cites letters of clearance from Iraqi officials (specifically, the deputy prime minister and prime minister's office) as its authorization for each step taken, Eskander argued these are insufficient under Iraqi and international law. Moreover, Eskander has received support from archivists in North America in his fight for the return of Iraqi records..$^{35}$

The core problem, from which all other issues stem, is the lack of clarity regarding the legal owner of the Baath Party records. After all, "title to any kind of property, including archival records, involves establishing rights of ownership and rights of possession through legal document with the transfer to the archives of both legal

34. Douglas Cox, “'Inalienable’ Archives: Korean Royal Archives as French Property under International Law," International Journal of Cultural Property 18, no. 04 (2011): 409-10, https:/ / doi.org/10.1017/ S0940739111000245.

35. John Gravois, "Disputed Iraqi Archives Find a Home at the Hoover Institution," Chronicle of Higher Education (Jan. 23, 2008), available online at https:/ / www.chronicle.com/article/Disputed-IraqiArchives-Find-a/ 426 [accessed 13 January 2018]; Montgomery, "Immortality in the Secret Police Files." 
title to and actual physical custody of the records." ${ }^{36}$ Incomplete title imposes limitations on archives, including the ability to reproduce, provide access to, dispose of, or transfer records. Archives, therefore, are required to exercise due diligence to ensure that a donation or loan is offered by a party that either has valid legal title and ownership or is an authorized agent of that party. ${ }^{37}$ Loan agreements transfer real property but leave untouched intellectual property rights unless otherwise specified by the agreement. Although archives often hold records with unclear provenance ("information regarding the origins, custody, and context of an item or collection" ${ }^{38}$ ), accepting records for which there is not a clear title should be avoided. In the case of Iraqi archives, although both the immediate lender (the IMF) and the creator of the records (Iraq's Baath Party) are clearly identified, neither party has title to the records. According to archival standards, it is therefore unclear what authority the IMF had to make decisions regarding the records without further investigation.

Typically, the record creator (the entity responsible for the production, accumulation, or formation of the records, which is distinct from the author, or the entity responsible for the content of the documents) would be presumed to have title to the records. For instance, according to the Canadian Copyright Act, excepting contributions to newspapers or other periodicals,

where the author of a work was in the employment of some other person under a contract of service or apprenticeship and the work was made in the course of his employment by that person, the person by whom the author was employed shall, in the absence of any agreement to the contrary, be the first owner of the copyright. ${ }^{39}$

This position becomes problematic due to the fact that the Iraq Baath Party no longer exists. According to Iraq's 2005 Constitution: "Any entity or program that adopts, incites, facilitates, glorifies, promotes, or justifies racism or terrorism or accusations of being an infidel (takfir) or ethnic cleansing, especially the Saddamist Ba'ath in Iraq and its symbols, under any name whatsoever, shall be prohibited." 40

The Baath Party records are thus best identified as orphan records whose presumptive legal owner no longer exists and has no successor body. However, that status does not mean that they are unowned. An argument can be made that the proper owner is the Iraqi government, as there is an open question of whether these are

\footnotetext{
36. Menzi L. Behrnd-Klodt, Navigating Legal Issues in Archives (Chicago: Society of American Archivists, 2008), 41.

37. Behrnd-Klodt, Navigating Legal Issues in Archives, 44, 71-72.

38. Pearce-Moses, A Glossary of Archival and Records Terminology and Information Sciences, 317.

39. RSC 1985, c C-42, s 13(3)).

40. “Iraq's Constitution of 2005," 2005, Article 7.1, constituteproject.org.
} 
public or private records. Although a political party is a private organization, Baathera Iraq was a one-party state, which creates difficulties in separating the Baath Party from the Iraqi government. Indeed, the link between the two bodies is such that Iraq underwent de-Baathification similar to the de-Nazification of Germany. ${ }^{41}$

There is precedent for treating the Baath records as governmental records. Other ruling party records, such as in Lithuania, Latvia, and Ukraine, have been treated as state records. Certainly, this is the view taken by Eskander and the academics who support his position. ${ }^{42}$ The nature of the records may also shed some light on this issue. According to the finding aid produced by the HI, the records include "the correspondence, reports, membership and personnel files, judicial and investigatory dossiers, administrative files and registers, and videorecordings ...relate[d] to political conditions in, and governance of, Iraq." ${ }^{43}$ The file structure divides material into 23 broad topics including Personnel, Correspondence (such as that between government agencies and/or individuals), High Command (like the Presidency, government of Iraq, and party leadership), National Events (such as events sponsored by the Iraqi government), State Institutions, Security, Prisoners of War, and Opposition. Thus, whether or not these records were created by the government itself, they were created by a body inextricably linked to the government of Iraq.

The position that the seized Baath Records constitute official governmental records is supported by a joint statement by the Association of Canadian Archivists and the Society of American Archivists: "for records of the Iraqi government, including the Baath Party records as an arm of the state, the archival principle of inalienability requires that they be returned to the national government of Iraq for preservation in the national archives." ${ }^{44}$ Recalling the discussion of inalienability, the principle of inalienability "prevents [public records] from being given, surrendered, or transferred to anybody except those the law allows to possess them" 45 and is linked to the role archives play in ensuring the accountability of public institutions. ${ }^{46}$ This would include the transfer or assignment of title. For instance, in the US, the National Archive and Records Administration (NARA) may "accept for deposit with the National Archives

\footnotetext{
41. Aysegul Keskin Zeren, "From De-Nazification of Germany to de-Baathification of Iraq," Political Science Quarterly 132, no. 2 (2017): 259-90.

42. Gravois, "Disputed Iraqi Archives Find a Home at the Hoover Institution"; Caswell, "'Thank You Very Much, Now Give Them Back," 219.

43. Hoover Institution Archives, "Register of the Hiẓb Al-Ba'th Al-'Arabī Al-Ishtirākī in Iraq [Ba'th Arab Socialist Party of Iraq] Records" (Stanford University, 2009), 2, available online at http:/ / pdf.oac. cdlib.org/pdf/hoover/2009C50.pdf [accessed 2 March 2018].

44. ACA/SAA, "ACA/SAA Joint Statement on Iraqi Records," Society of American Archivists, April 22, 2008, available online at https://www2.archivists.org/statements/acasaa-joint-statement-on-iraqirecords [accessed 13 January 2018].

45. Pearce-Moses, A Glossary of Archival and Records Terminology and Information Sciences, 200

46. Terry Eastwood, "Reflections on the Goal of Archival Appraisal in Democratic Societies," Archivaria 54 (2002): 69; Caswell, "Rethinking Inalienability," 114.
} 
of the United States the records of a Federal agency, the Congress, the Architect of the Capitol, or the Supreme Court determined by the Archivist to have sufficient historical or other value to warrant their continued preservation by the United States Government." ${ }^{\text {"77 }}$ The US retains title to all records transferred to NARA unless "unless otherwise authorized by Congress." ${ }^{38}$ Similarly, the Library and Archive of Canada is "the permanent repository of publications of the Government of Canada and of government and ministerial records that are of archival value." ${ }^{49}$ Moreover, government and ministerial records cannot be disposed of without its consent. ${ }^{50}$ This is in agreement with the International Council on Archives statement that "national laws agree in conferring the status of inalienable and imprescriptible public property on public records." ${ }^{51}$ Thus, according to the principle of inalienability, if the Baath Party records are public records then the state owns them and, barring legislative intervention, the proper repository is most likely the Iraq National Archives and Library. Although Eskander cites two laws that may provide a similar legal foundation to the US and Canada, ${ }^{52}$ it is difficult to evaluate this claim without more information about the laws in question, as available sources of Iraqi laws are in Arabic.

Based on archival principle and practice accepted both internationally and in the US, we can conclude that the records are almost certainly the property of the government of Iraq. In turn, this means their disposition and custody should be consistent with the principle of inalienability. Iraq has acted formally on this point. In January 2008, the Iraqi parliament passed the Accountability and Justice Law, in which "files of the dissolved Baath Party shall be transferred to the Government in order to be kept until a permanent Iraqi archive is established pursuant to the law." ${ }^{33}$ Neither the IMF, INLA, nor HI were mentioned by the law..$^{54}$ Although Eskander claims the National Board of Accountability and Justice supports the return of the records, ${ }^{55}$ this "support" does not clarify whether the INLA will be the final repository should the records be repatriated to Iraq. However, there is now widespread agreement that the records belong to Iraq. Following a meeting with an official Iraqi delegation, the HI agreed that the records were the property of the

\footnotetext{
47. 44 U.S.C. $\$ 2107$.

48. 44 U.S.C. $\S 2107$.

49. Library and Archives of Canada Act, SC 2004, c 11, s 7(d) [LAC].

50. LAC, s 12(1).

51. International Council on Archives, "The View of the Archival Community on Settling Disputed Archival Claims."

52. Gravois, "Disputed Iraqi Archives Find a Home at the Hoover Institution"; "Iraqi Legal Database," Internet Archive, available online at https:// web.archive.org/web/20090129112539/http:/ / iraqild.org/ [accessed 9 March 2018].

53. Montgomery, "Immortality in the Secret Police Files," 328.

54. Hugh Eakin, "Iraqi Files in the U.S.: Plunder or Rescue?," New York Times (July 1, 2008), available online at www.nytimes.com/2008/07/01/books/01hoov.html [accessed 13 January 2018]; Montgomery, "Immortality in the Secret Police Files," 317.

55. Saad Eskander, "Saad Eskander's Open Letter to the Hoover Institution," Library Juice (June 21, 2008), available online at http:/ /libraryjuicepress.com/blog/?p=439 [accessed 13 January 2018].
} 
people of Iraq, which is represented by the elected government. ${ }^{56}$ Moreover, "original documents of the Ba'th Party in the custody of the Iraq Memory Foundation have been or will be returned to Iraq. Those in Baghdad were returned to the Iraqi government by 2009. Those in the U.S. will be returned at an undetermined future date." ${ }^{57}$ Although neither the HI nor the IMF has asserted ownership over the records and both agree that they should be repatriated to Iraq ${ }^{58}$ neither entity committed itself to a time or conditions. At the same time, neither party has the right to make such a determination given that they do not hold legal title to the records.

The IMF is neither the creator of the Baath Party records nor was it designated by law, either pre- or post-2003, as their proper repository. Thus, each action must be examined separately to determine both the source and scope of its authority. In other words, even if the IMF had proper authority to collect the records, that authority does not automatically include permission to remove them from Iraq or to transfer them to the HI. According to Makiya, permission was obtained from the CPA to take custody of these records in 2003, which Douglas Cox agrees was within its authority. ${ }^{59}$ Because this was rescinded when sovereignty was transferred to the interim Iraqi government, "the subsequent authority of the IMF to continue to hold the records and transport them to the U.S. would be coextensive with the consent of the Iraqi government." ${ }^{\prime 60}$ In 2004, the IMF reportedly received permission from the postwar government to collect documents related to the harmful actions of the previous regime to be preserved in a national institution in Baghdad. ${ }^{61}$ Although legislative authority would have been preferable due to its unambiguity, there is no inherent reason why this cannot be sufficient authority for the collection of the records by the IMF.

It might also be argued that the US had a legal obligation to ensure the preservation of Iraqi cultural property, which includes archives. Both the Convention for the Protection of Cultural Property in the Event of Armed Conflict and the Convention on the Means of Prohibiting and Preventing the Illicit Import, Export and Transfer of Ownership of Cultural Property explicitly include archives in their definitions of cultural property. Moreover, international outrage over the US military's failure to protect the Iraq Museum in Baghdad suggests at least a moral obligation on their part to ensure the survival of these records as an aspect of Iraq's cultural property. ${ }^{62}$ Given that the

56. Montgomery, "Immortality in the Secret Police Files," 318.

57. Hoover Institution Archives, "Register of the Hiẓb Al-Ba'th Al-'Arabī Al-Ishtirākī in Iraq [Ba'th Arab Socialist Party of Iraq] Records."

58. Montgomery, "Immortality in the Secret Police Files," 318.

59. Gravois, "Disputed Iraqi Archives Find a Home at the Hoover Institution"; Cox, "Archives and Records in Armed Conflict," 1047.

60. Cox, "Archives and Records in Armed Conflict," 1048

61. Eakin, "Iraqi Files in the U.S.: Plunder or Rescue?"

62. See, for instance, Matthew Bogdanos, "The Casualties of War: The Truth about the Iraq Museum," American Journal of Archaeology 109, no. 3 (2005): 477-526; Lawrence Rothfield, The Rape of Mesopotamia: Behind the Looting of the Iraq Museum (Chicago: The University of Chicago Press, 2009). 
Americans appeared to have no plan for safeguarding the documentary heritage of Iraq despite urging from bodies such as Human Rights Watch and the Society of American Archivists, ${ }^{63}$ there is a certain pragmatic justification that can be offered for authorizing a private organization to collect and therefore save these records. Certainly, during the war there were clear problems with lack of protection of Iraq's documentary heritage, including both accidental and deliberate destruction. ${ }^{64}$ This resulted in the dispersal of Iraqi state records to numerous parties, including the American authorities, Iraqi political groups, and NGOs. ${ }^{65}$

Acting promptly to ensure the preservation of the Party records was an important action for which the IMF should be commended, particularly given the failures of the American military in this regard. In archival terms, by prompt action the IMF may have limited the damage to the records, as information about the record's chain of custody, creator, and context of creation remains available, thus satisfying at least part of the archival concern for provenance. Provenance, however, has two dimensions:

This principle may have an outward application, which is to respect the archival body as it was created by an individual, group or an organization as a whole. We call this respect des fonds. The principle of provenance may also be applied inwardly, respecting the original order given to the documents by the documents by the administration which created them. ${ }^{66}$

It is unclear whether the IMF's seizure compromised or lost information regarding the original order of these records, which can provide information about the relationships between the records or the manner in which the creator used them. Even if the original order was lost, that may still be an acceptable price to pay for the preservation of the records. Although the external aspect, respect des fonds, may be substantially intact, Cox makes an important point: "the records' journey and the corresponding facts are not authoritatively documented and can only be cobbled

63. Human Rights Watch, "Iraq: Protect Government Archives from Looting," Human Rights Watch (Apr. 9, 2003), available online at https: / /www.hrw.org/news/2003/04/09/iraq-protectgovernment-archives-looting [accessed 9 March 2018]; Hania Mufti and Eric Stover, "Iraq: State of the Evidence" (New York: Human Rights Watch, 2004), 6, available online at https: / www.hrw.org/sites / default/files/reports/iraq1104.pdf [accessed 4 March 2018]; The Society of American Archivists, "Statement on Iraqi Archives," SAA (Apr. 2003), available online at http:/ /www.archivists.org/statements/ iraqi_archives.asp [accessed 9 March 2018].

64. Nabil Al-Tikriti, "'Stuff Happens': A Brief Overview of the 2003 Destruction of Iraqi Manuscript Collections, Archives, and Libraries," Library Trends 55, no. 3 (2007): 730-45; Ian M. Johnson, “The Impact on Libraries and Archives in Iraq of War and Looting in 2003-A Preliminary Assessment of the Damage and Subsequent Reconstruction Efforts," The International Information \& Library Review 37 (2005): 209-71; Mufti and Stover, "Iraq: State of the Evidence."

65. Mufti and Stover, "Iraq: State of the Evidence," 4-14.

66. Peter Horsman, "Taming the Elephant: An Orthodox Approach to the Principle of Provenance," in The Principle of Provenance: Report from the First Stockholm Conference on the Archival Principle of Provenance, 2-3 September 1993 (Stockholm: Swedish National Archives, 1994), 51. 
together from news articles and interviews that are not always consistent." ${ }^{67}$ This lack of administrative documentation undermines the chain of custody, which in turn undermines the credibility of the record by creating doubts about authenticity (that is to say, that they are what they say they are, and how they were compiled and used) and about the integrity of the whole after time spent in foreign hands. This may limit their value as evidence, an important characteristic of records. ${ }^{68}$

The history of the Baath Party records makes the lack of a pre-existing plan for Iraq's documentary evidence abundantly clear. Although the IMF was given permission to found its institution in 2003, by 2004 the CPA intended to create a National Archive and consolidate all state archives in non-US hands under the Iraqi human right ministry acting as the central repository. ${ }^{69}$ Moreover, it ordered the establishment of the National Foundation for Remembrance similar to the IMF plan. ${ }^{70}$ While no law regulating the possession and use of state archives was passed, ${ }^{71}$ it is clear that there was no intention to allow the IMF to retain control of the records. Nevertheless, in 2005, the IMF transferred the records to the US due to concerns about the deteriorating security situation in Iraq. ${ }^{72}$ Transporting the records outside Iraq is more problematic than their collection due to the prevalence of international and domestic law governing the import and export of cultural property.

With the permission of officials in the prime minister's office, the IMF entered into an agreement with the US military to transfer the records to American soil. ${ }^{73}$ The military agreed to transport the records to the US, where they would be scanned by government contractors before returning the originals to the IMF. Yet, according to Eskander, 1969 Iraqi legislation no. 111 "imposes severe punishment on those who destroys, hides, steal, forge, publish or remove official Iraqi documents. The legislation also imposes severe punishment on those individuals who collaborate with and provide foreign states with Iraqi documents." ${ }^{\prime 4}$ If this is the case, it would appear that the prime minister's office does not have the authority to transfer records outside the country unless there is additional legislation allowing for extraordinary circumstances, as there is no indication of a governmental exemption. For instance, the Convention for the Protection of Cultural Property in the Event of Armed Conflict does permit the transfer of cultural property outside a country under special protection

67. Cox, "Archives and Records in Armed Conflict," 1044.

68. Luciana Duranti, "The Archival Bond," Archives and Museum Informatics 11 (1997): 213-18.

69. Mufti and Stover, "Iraq: State of the Evidence," 18-19; Robert F. Worth, "The Struggle for Iraq:

The Past; Planning a Museum to Tell Iraq’s Story," New York Times (Sept. 9, 2003).

70. Montgomery, "Immortality in the Secret Police Files," 314.

71. Mufti and Stover, "Iraq: State of the Evidence," 20.

72. Eakin, "Iraqi Files in the U.S.: Plunder or Rescue?"

73. Montgomery, "Immortality in the Secret Police Files," 316; Montgomery, "Saddam Hussein's Records of Atrocity," 358.

74. Eskander, "Saad Eskander's Open Letter to the Hoover Institution," para 8. 
or urgent cases (neither of which apply here) and Iraq's implementing legislation may provide additional insight. ${ }^{75}$ Regardless, there is no indication that there was any sort of permission given by the Iraqi government for the scanning operation.

While private contractors such as the IMF were given blanket immunity from Iraqi law (Order 17 of the Coalition Provisional Authority) from 2003 until 2009, immunity merely defends IMF's staff from prosecution in Iraq; it does not provide authority to initiate action. Both Iraq and the US are State Parties to the Convention on the Means of Prohibiting and Preventing the Illicit Import, Export and Transfer of Ownership of Cultural Property. Although individual states have unique implementing legislation, general caution should be exercised in regard to the export of cultural property from any state party to the convention. An examination of Iraq's legislation may yield further restrictions on the export of public records or a basis for the prime minister's office's actions, but it is subject to the linguistic limitations previously described. Although these records might also be considered military intelligence, which might invoke a separate analysis, ${ }^{76}$ the circumstances of the collection, the delayed transfer to American custody, and their eventual transfer to the HI argue against this interpretation. This argument might be more compelling if, for instance, the US military had collected the records in the first place or demanded that they be turned over to their care and custody.

The third action taken by the IMF that requires examination is its transfer of the records to the HI under a five-year loan agreement. After the US military finished scanning the files, both the originals and a digital copy of the record were returned to the IMF as per their original agreement. Given that the IMF did not possess title to these documents, it is not clear why the US honored this agreement rather than retain possession for eventual return to Iraq. Although, as Bruce Montgomery notes, there is a lack of international legal instruments to govern the return of records captured during armed conflict, there remain a number of cases in which the US has done so. ${ }^{77}$ This includes records seized during the Mexican-American War, the Philippine War, German and Japanese World War II records, and the invasions of Grenada and Haiti. If other captured public records were treated as inalienable, it should follow that the Baath Party records should be as well, particularly as these are not, strictly speaking, captured records. Nevertheless, entrusting them to a private organization, albeit a foreign one, is at least consistent with their seizure by a private entity in Iraq (in this case, the IMF). Although it could be regarded as an expedient good-faith effort at stabilizing and preserving the material, it also complicated the custodial situation dramatically.

75. Convention for the Protection of Cultural Property in the Event of Armed Conflict, 14 May 1954, 249 UNTS 215 (entered into force 7 August 1956, accession by Canada 11 December 1998), Art. 12, 13.

76. See, for instance, Montgomery, "Saddam Hussein's Records of Atrocity"; Cox, "Archives and Records in Armed Conflict."

77. Montgomery, "Saddam Hussein’s Records of Atrocity," 333-36. 
At the time the records were ready for return, both the IMF and the HI indicated doubt that Iraq was ready for these records and lacked a proper repository ${ }^{78}$ However,

the terms of the agreement implied that Makiya and IMF, private nonstate actors, would continue to exert stewardship over the files. Even though the IMF and Hoover claimed that the documents remained the property of the Iraqi people, the agreement all but cast the IMF in the position of a sovereign government that could negotiate with the Iraqi government when and under what conditions the archive would be repatriated. ${ }^{79}$

While it is clear that this was a loan (specifically, a five-year loan agreement, presumably renewable) and not an outright gift to the HI, the IMF is only entitled to enter into such an arrangement if it is an authorized representative of the title holder. If the IMF did not have the authority to make this loan agreement, the HI could find itself subject to legal action (that is, replevin) to return the records to their rightful owner. ${ }^{80}$ Given that Richard Sousa, the Hoover Institution's senior associate director, admitted that "he does not know who technically owns the documents," ${ }^{\prime 1}$ it seems unlikely that the HI would be able to establish the presence of due diligence. As public records are inalienable, their return is not subject to statutes of limitations. ${ }^{82}$ There is, therefore, considerable legal risk involved in accepting the records.

As previously discussed, according to the Iraqi Accountability and Justice Law, all "files of the dissolved Baath Party shall be transferred to the Government in order to be kept until a permanent Iraqi archive is established pursuant to the law." ${ }^{\prime 3}$ Although this law provides substantial clarification as to who owns the records and where they should be kept, in making his argument for their transfer to the HI, Makiya instead cited authorization for his actions from letters from the Iraqi prime minister's office, the Deputy Prime Minister, and Senior Deputy Minister of Culture in 2007 and $2008 .{ }^{84}$ Thus, IMF asserted that the organization had legal custody

\footnotetext{
78. Eakin, "Iraqi Files in the U.S.: Plunder or Rescue?"; Gravois, "Disputed Iraqi Archives Find a Home at the Hoover Institution."

79. Montgomery, "Immortality in the Secret Police Files," 316.

80. See, for instance, Elena S. Danielson, "Archives and the Ethics of Replevin," Journal of Information Ethics 22, no. 2 (2013): 110-40; Eleanor Mattern, "A Six-Stage Process for Recovery of Public Records: Replevin and the State of North Carolina," Archival Science 16 (2016): 195-212; Ryan Speer, "State Property or Cultural Property? The Limitations of Replevin as an Interpretative Framework for Disputed Archives," Journal of Information Ethics 22, no. 2 (2013): 102-09.

81. Adam Gorlick, "Saddam Hussein's Papers, along with Controversy, Find a Temporary Home with the Hoover Institution," Stanford News (June 18, 2008), available online at https:/ / news.stanford.edu/ news/2008/june18/iraq-061808.html [accessed 9 March 2018].

82. Mattern, "A Six-Stage Process for Recovery of Public Records," 197.

83. Montgomery, "Immortality in the Secret Police Files," 328.

84. John Gravois, "A Tug of War for Iraq's Memory," Chronicle of Higher Education (Feb. 8, 2008); Eakin, "Iraqi Files in the U.S.: Plunder or Rescue?"; Montgomery, "Immortality in the Secret Police Files," 317.
} 
of the documents based on a mandate from the elected government of Iraq. ${ }^{85}$ This was disputed by Eskander with support from the acting Minister of Culture and other officials including Iraqi parliamentarians.$^{86}$ This conflict between and among the legislative and executive branches of government suggests both a lack of communication as well as misunderstandings about who, precisely, has the ability to make decisions regarding the records. This, in turn, casts doubt on the authorization of the transfer to the HI. This position is substantiated by the International Council on Archives: "the alienation of public archives can ... only occur through a legislative act [not an executive act] of the State which created item." ${ }^{87}$ Thus, only the Accountability and Justice Law or the government of Iraq itself through additional legislation can determine the disposition of these records, and all actors are bound by that legislation. It is both possible and likely that the prime minister's office exceeded its authority, particularly after the passage of the Accountability and Justice Law. It is, therefore, unsurprising that a three-member Iraqi delegation formally requested the return of the Baath Party records in 2010. ${ }^{88}$

Harvard University nearly reached an agreement to house a digital copy of the records prior to the HI agreement. The university eventually withdrew from negotiations to house both the digital and physical records due to concerns over provenance, the sensitivity of the records, and their legal status. ${ }^{89}$ Indeed, it is difficult to see how an archival institution could fully protect the third-party privacy rights of the individuals named in the records without input from the Iraqi government. Although the $\mathrm{HI}$ is an American institution, and thus bound by American law, there is an ethical and moral obligation to ensure that Iraqi expectations about privacy and access are met. Typically, special conditions or restrictions would be identified as part of the loan agreement. A useful comparative case is the handling and access to records of the German Ministry of State Security (or Stasi) of the former German Democratic Republic (East Germany). Determining the fate of these records was not straightforward, as the decision had to balance 1) the personal right of individuals to access and privacy and 2) the public interest (examples: victim compensation, prosecution, administrative reconstruction). ${ }^{90}$ The resulting German law gives priority to individuals to access information collected about themselves but does not allow individuals or victims to access other files, mandating redac-

85. Caswell, "Thank You Very Much, Now Give Them Back," 217-18.

86. Eakin, "Iraqi Files in the U.S.: Plunder or Rescue?"; Eskander, "Saad Eskander's Open Letter to the Hoover Institution.”

87. International Council on Archives, "The View of the Archival Community on Settling Disputed Archival Claims."

88. Montgomery, "Immortality in the Secret Police Files," 317-18.

89. Gravois, "A Tug of War for Iraq's Memory"; Montgomery, "Immortality in the Secret Police Files," 316.

90. John Miller, "Settling Accounts with a Secret Police: The German Law on the Stasi Records," Europe-Asia Studies 50, no. 2 (Mar. 1998): 309, https:/ / doi.org/10.1080/09668139808412537. 
tion of information on other individuals and third parties. ${ }^{91}$ There is, however, an important exception made to privacy, as victims have access to records naming people who informed on them. Research in the Stasi records is also subject to strict access rules. Although files relating to operational objectives and implementation are readily available, there are detailed procedures that come into play when an individual's name appears in the records that require redaction or a written release by that individual. ${ }^{92}$ Moreover, the fate of the Stasi archive was determined by the all-German Bundestag, which ratified the Stasi Files Bill in December 1991. There has been no comparable process for the records held at the HI, nor would the HI necessarily be bound by any such Iraqi legislation although it may certainly choose to honor any such legislation.

Although the sensitivity of these records is reflected in the fact that the HI does not make these records available online, this actually creates a new problem. As of 2014, the HI held the only copies of the records taken from the Baath Party in 2003. ${ }^{93}$ Therefore, Iraqis effectively have no access to these records despite the fact that such records play a fundamental role in consolidating individual and collective rights in a new political state (examples: right to the integrity of written memory, right to truth). ${ }^{94}$ Moreover, societal trust in records is affected by both circumstances and the nature of the institution in which records are held. ${ }^{95}$ Although the $\mathrm{HI}$ is an appropriate location in terms of its own collection scope, placing these records in well-intentioned foreign hands without the consent of the Iraqi people may diminish their perceived trustworthiness as previously discussed. Finally, there are also issues with consent to deal with. As one article asked, "by what right will US academia obtain and research the Iraqi records without Iraqis' consent or participation?"96 Although the records are relevant outside Iraq, such research should not come at the expense of those most directly affected. None of this is to say that the Baath party records have not been treated well, according to existing archival standards. Their finding aid is available online and is admirably complete and professional. As Bruce Montgomery notes, "there is no evidence to suggest that either institution has been anything

91. Karsten Jedlitschka, "The Lives of Others: East German State Security Service’s Archival Legacy," American Archivist 75, no. 1 (Apr. 2012): 89, https:// doi.org/10.17723/aarc.75.1.c6555155715775nq.

92. Jefferson Adams, "Probing the East German State Security Archives," International Journal of Intelligence and CounterIntelligence 13, no. 1 (Jan. 2000): 23-24, https:// doi.org/10.1080/088506000304925.

93. Nitish Kulkarni, "Iraqi Ambassador Visits Stanford for Hoover Institution Conference on SaddamEra Documents," The Stanford Daily (June 3, 2014), available online at https:/ / www.stanforddaily. $\mathrm{com} / 2014 / 06 / 03$ /iraqi-ambassador-visits-stanford-for-hoover-institution-conference-on-saddam-eradocuments/ [accessed 9 March 2018].

94. Antonio Gonzalez Quintana, "Archives of the Security Services of Former Repressive Regimes" (Paris: UNESCO, 1997), 10-11, available online at http:/ / unesdoc.unesco.org/ images/0014/001400/140074e.pdf [accessed 3 March 2018].

95. Caswell, "Rethinking Inalienability."

96. Salah Nasrawi, "Iraq's Stolen Memory," Al-Ahram Weekly Online (Nov. 3, 2011), available online at http:/ / weekly.ahram.org.eg/archive/2011/1071/re10.htm [accessed 5 March 2018]. 
but a serious steward and protector of these materials." ${ }^{\text {97 }}$ This is particularly notable in comparison with archives held by the Soviet Union, where only minimal inventories were created and many records were separated from their original context or fonds. ${ }^{98}$ The issue is not, however, the Baath Party records' treatment by the HI, but rather the ongoing disregard for questions of ownership and the principle of inalienability by the US government, IMF, and HI.

While is it easy to say that this situation could have been avoided by careful examination of who owns these records and, thus, who has the authority to collect, export, and transfer these records, it is much harder to say what should be done in future cases. Certainly, military forces need greater attention to cultural property issues including archives. Not unlike the "Monuments Men" of World War II, some countries, such as the Netherlands, Italy, and Austria, have specialist units and military staff for the protection of cultural property. ${ }^{99}$ Although there is international consensus on the inalienability of public records, this is undermined by a degree of ambiguity in regard to those seized during armed conflict. ${ }^{100}$ There is also the possibility of working through an organization such as Blue Shield International, which is focused on the protection of cultural property in armed conflict and natural disasters. Moreover, the American Society of Archivists provides a guide for disaster planning and prevention that may be helpful in developing principled interventions for third parties as well as the governments involved in a crisis. ${ }^{101}$ An instrument such as a UNESCO convention is likely the most appropriate wholistic solution, but without an enforcement mechanism it may be of limited value. For instance, the Convention on the Means of Prohibiting and Preventing the Illicit Import, Export and Transfer of Ownership of Cultural Property lacks mechanisms for the return of illegally exported material. Established in 1978, the accompanying UNESCO Intergovernmental Committee for Promoting the Return of Cultural Property to Its Countries of Origin or Its Restitution in Case of Illicit Appropriation is limited by the requirement that claims are to be pursued by a UNESCO member state; an advisory capacity that emphasizes negotiation for the resolution of disputes, and its inability to mediate in claims against individuals or national institutes. ${ }^{102}$ Underscoring these limitations, as of 2009, only eight

\footnotetext{
97. Montgomery, "Saddam Hussein’s Records of Atrocity," 369.

98. Grimsted, "Displaced Archives and Restitution Problems," 48-60.

99. Julian Radcliffe, "The UK’s Training and Awareness Programme," in Archaeology, Cultural Property, and the Military, ed. Laurie Rush (Woodbridge, UK: Boydell Press, 2010), 28.

100. See, for instance, Cox, "Archives and Records in Armed Conflict"; Bruce Montgomery, "Reconciling the Inalienability Doctrine with the Conventions of War," American Archivist 78, no. 2 (2015): 288-316, https: / / doi.org/10.17723/0360-9081.78.2.288.

101. SAA, "Annotated Resources," Society of American Archivists, n.d., available online at https:// www2.archivists.org/initiatives/mayday-saving-our-archives/annotated-resources\#tutorials [accessed 17 March 2018].

102. Tamara Kagan, "Recovering Aboriginal Cultural Property at Common Law: A Contextual Approach," University of Toronto Faculty Law Review 63 (2005): 8.
} 
cases have been submitted to committee. ${ }^{103}$ It is, however, important not to limit any such mechanism to states, as that would limit its utility to Indigenous Peoples. In the interim, archives are regrettably left to their own judgment about how to best follow existing best practices.

Although all parties now agree that the Baath Party records are the property of the people of Iraq, which is in keeping with the inalienability of public records, this has not solved the problems of custody and control. While it would appear that their collection by the IMF was, in fact, properly authorized, this does not extend to subsequent actions. There is, for instance, doubt that the export of these records was properly authorized by the Iraqi government. For this, the U.S. military must also take a share of the blame, as it facilitated their transfer to American soil and allowed the subsequent transfer to the $\mathrm{HI}$ in contradiction to its own actions in similar cases. While there was a degree of support for the transfer to the HI from Iraqi officials, this was insufficient to authorize a loan agreement, particularly following the 2008 Accountability and Justice Law. Moreover, given the principle of inalienability, the concerns of other archival repositories, the condemnation from its professional society, and its own acknowledgment of the problems with title, the HI should never have accepted these records. While the concern for the preservation of these documents by the IMF and HI is commendable, they have neither the right to decide their proper home, nor when it is the "right time" to return these documents to Iraq. However, because the records are no longer under the control of the US government, the IMF and HI will nevertheless be empowered to make these decisions unless the government of Iraq brings the matter to an American court.

Although most archives will never face the question of whether to accept records acquired in this manner, many will have to navigate questions about whether or not to acquire records or objects from an entity that did not create them. One valuable lesson from this case is that the principle of inalienability can apply even if cases where the government itself is not the direct creator of the records. This requires an expanded understanding of the relationships involved in determining ownership, which may also be valuable in finding homes for orphaned records. There are also clear issues of privacy and consent that are relevant beyond this case, particularly if records include research data of any kind. Thus, although the case of Iraq's Baath Party records has an international character and exceptional circumstances, the core questions of who owns the records and who has the authority to take actions in regard to those records is relevant in a wide range of circumstances.

103. Lyndel V. Prott, "UNESCO International Framework for the Protection of the Cultural Heritage," in Cultural Heritage Issues: The Legacy of Conquest, Colonization, and Commerce, eds. James A.R. Nafziger and Ann M. Nicgorski (Leiden, The Netherlands: Martinus Nijhoff, 2009), 263. 